\title{
EDITORIAL
}

\section{Transparency Is Turning a Corner}

\section{INTRODUCTION}

This editorial has nothing to do with tax and, at the same time, it is all about tax; it is about reporting on tax, not towards the fisc but towards the public.

We seem to live in an age in which trust is leaving the system. There is diminishing trust in society and its institutions as well as in business. One of the areas where the trust gap is highly visible is taxation of business: the popular belief is that multinationals do not pay tax, at least not their fair share, and the citizens pick up the bill. While the discomfort in society about the tax contribution by multinationals has been around for a long time, it has built up significantly during the last decade beginning with the financial crisis. During this period, the distrust translated into an abundance of anti-avoidance measures that were partly channelled and coordinated through the G20/OECD Base Erosion and Proft Shifting (BEPS) Project and to increased calls for transparency towards the public about the tax behaviour of multinationals not only relating to their tax contribution but also to their tax strategy and tax governance.

The trust gap as it has emerged in the tax environment cannot be understood in isolation. Since the 1970s, the Western world has been dominated by neoliberalism, in part stimulated by the policies of US President Ronald Reagan and UK Prime Minister Margaret Thatcher. Add to that the fall of the Berlin Wall and the disintegration of the Soviet Union, widely interpreted as the victory of capitalism over communism, and multilateral and regional trade agreements leading to an increasingly globalized world, and we have the backdrop against which to assess the current situation. While there have been regional financial crises and industry bubbles before, the 2008/2009 financial crisis may mark a turning point for the neoliberalist global economy. Even though the world had recovered significantly from that crisis prior to the current crisis caused by the Coronavirus disease 2019 (COVID-19) pandemic, trust had begun to crumble. There currently appears to be broad recognition that capitalism needs to be more inclusive and evidenced, among others, by a drive to move from shareholder capitalism to stakeholder capitalism that the trust gap between business and society needs mending. It is in this context that tax transparency is developing.

\section{THe tIMELINE}

Tax transparency towards governments has developed progressively over the last two decades, not in the least through the G20/OECD BEPS Project, including country-by-country reporting (CbCR). There is also tax transparency of the very uncomfortable type, i.e., that brought about by hearings, including congressional hearings in the United States, and other inquiry committees in, among others, Australia and the United Kingdom and through the fiscal state aid matters pursued by the European Commission. It is also important to note the transparency resulting from the various investigations released by the International Consortium of Investigative Journalists. However, the transparency towards tax authorities and that brought about by the other forced disclosures are not the topic of this editorial.

Mandatory and voluntary transparency by multinationals themselves towards the public is emerging. Already in 2003, there were the Extractive Industries Transparency Initiative Principles followed by the US Dodd-Frank Wall Street Reform and Consumer Protection Act in 2010 and amendments to the EU Accounting Directive in 2013, both also relating to the extractive sector, and also the Capital Requirements Directive IV with transparency for banks in 2013. However, the world has moved on. Australia developed transparency principles and minimum standards in 2015. There was an EU proposal for public CbCR and the UK requirement to publish a tax strategy followed in 2016. The B Team Responsible Tax Principles were introduced in 2018, the Global Reporting Initiative (GRI) Standards that include public CbCR were adopted in 2019, and the ESG metrics document was published by the World Economic Forum in 2020. Additionally, the recently published public $\mathrm{CbCR}$ breakthrough in the EU brokered by the Portuguese Presidency was significant.

In addition to the transparency initiatives by regulators, standard-setters and businesses, there is increasing focus on transparency by institutional investors arising in the context of the UN Sustainable Development Goals.

As can be concluded from the above timeline, increased focus on tax transparency was developing well before the 
COVID-19 pandemic, however, this pandemic has clearly provided for another push towards more transparency.

\section{EU proposal public CBCR}

The European Commission first published a proposal for public CbCR in April 2016. This must have been frowned upon in certain corners of the OECD membership as the understanding leading to the adoption of BEPS Action 13 seemed to be that transparency would be towards the tax authorities only. In July 2017, the European Parliament formulated its own position, but the EU Member States in and outside of the EU Council were not able to agree. That disagreement included the theme of whether the adoption of a directive would require unanimity or only a qualified majority.

By the time this editorial will be published, a proposal for a directive may very well have been adopted, if not in form then through political agreement. The council's recent compromise draft directive was discussed during an informal council meeting on 25 February 2021 and then approved by the Member States' permanent representatives in meeting on 3 March 2021. These two steps effectively paved the way for discussions between the presidency and the European Parliament and against the background of the enthusiasm expressed by certain longtime members of the European Parliament that have been very vocal on transparency; the stars seem to be aligned for a compromise. That does not mean that agreement on a proposal and then its adoption is certain by now, however, the momentum seems to be there.

While the EU Presidency's proposal is less comprehensive than CbCR reporting as per BEPS Action 13 and under GRI 207-4, it will still result in significant disclosure that will enable the reader to form a well-informed opinion on the taxes borne by the reporting multinational.

While there are some interesting and significant differences between the presidency's proposal and that of the European Parliament, which will probably have been resolved by now, a very interesting question is whether the final proposal will have extra-territorial effect, meaning that also non-EU multinationals will be within its scope. In the current council draft, an EU-affiliate of a non-EU multinational would be obligated to publish and make the required reporting accessible, but the instruments to make that happen seem rather ineffective. If the report is not available, the affiliate must request the ultimate parent to provide the information and, if it is not provided, then the affiliate should explain why that is the case; stated differently, 'comply or explain'. It is conceivable that some EU-based multinationals will contend that the lack of enforceable extra-territorial effect will put them at a competitive disadvantage vis-à-vis multinationals based outside the EU. The European Parliament may be inclined to pursue other methods to nudge nonEU multinationals into the reporting mode, perhaps a bit more subtle than those explored in the past, e.g., in the US Foreign Accounts Tax Compliance Act.

\section{The tRend}

Public CbCR has fierce proponents and equally fierce opponents. While the argument used by individuals and organizations in each of these categories are relevant and important, they should not distract attention from the underlying trend and pressure from within society towards more disclosure not only of taxes borne but also of the governance and strategy towards tax adopted by multinationals. The pressure will continue and not only come from politicians, non-governmental organizations, and certain governments but also from financial accounting standard-setters, certain regulators and, not in the least, from institutional investors that are increasingly developing transparency standards in the ESG context for their investments. While protection of sensitive information is important - and that importance must be recognized - the current trend also affords a significant opportunity to narrow the trust gap. Many multinationals have an important and good story to tell about their tax contribution comprising not only the taxes borne by these companies but also those withheld or otherwise collected. Often, their fiscal footprint is quite significant. In due course, hopefully, more transparency will also help reduce the sometimes violent rhetoric towards business which, in and of itself, erodes trust.

Stef van Weeghel

Professor of international tax law, University of Amsterdam, Global Tax Policy Leader, PwC E-mail: s.vanweeghel@uva.nl. 